\title{
IFNL4 Gene
}

National Cancer Institute

\section{Source}

National Cancer Institute. IFNL4 Gene. NCI Thesaurus. Code C124079.

This gene plays a role in antiviral responses and JAK-STAT pathway activation. 